\title{
Ecology of Bats Hibernating Underground in Central Poland
}

\author{
Grzegorz LESIŃSKI
}

\begin{abstract}
Lesiński G., 1986: Ecology of bats hibernating underground in central Poland. Acta theriol., 31, 37: 507-521 [With 6 Tables \& 3 Figs.]

Bats hibernating in underground parts of a fortress in central Poland were studied over three seasons: 1979/80, 1980/81, and 1981/82.

A total of 1072 individuals were marked, representing nine species. The most abundant were Barbastella barbastellus $(48.2 \%)$ and Myotis daubentoni $(35.3 \%)$. It has been found that the coolest and most exposed places were occupied by $B$. barbastellus and $P$. austriacus, contrary to bats of the genus Myotis. "Autumn" bats were distinguished, M. myotis and $M$. daubentoni, most abundant in October, and "winter" species occupying the fortress from late October or early November $B$. barbastellus, $M$. nattereri, and $P$. auritus. There was a continuous exchange of individuals over the hibernation period, and the proportion of individuals noted more than once did not exceed $40 \%$. In populations of $E$. serotinus and B. barbastellus males outnumbered females. The sex ratio in $M$. daubentoni and $B$. barbastellus varied over the hibernation period. The duration of hibernation, as estimated from changes in body weight, was 175-190 days for $M$. daubentoni and 140 days for $B$. barbastellus.

[Dept. Vertebr. Ecol., Inst. Ecol. Polish Acad. Sci., Dziekanów Leśny, 05-092 Łomianki, Poland]
\end{abstract}

\section{INTRODUCTION}

Ecological studies on bats hibernating underground have been in focus of scientists for many reasons. Although there are many data on this subject, the literature based on long-term studies of individually marked bats is scarce, and some large areas, for example, central and eastern Poland, were not investigated at all.

The purpose of this paper is to determine the species composition of bats hibernating underground in climatic conditions of the lowland of central Poland, and also to assess habitat preferences of different species. Changes in numbers of bats are described, also their population stability, sex ratio and its changes. An attempt was made to assess the duration of hibernation for several species. 


\section{STUDY AREA}

\subsection{Geographical Location and Climate}

In northern part of the Warsaw province there is a former fortress Modlin. The central part of the fortress, located on the Narew river, is surrounded with a circle of smaller forts. The study was carried out in six abandoned forts, where hibernating bats were found during preliminary observations (Lesiński, 1980).

'The forts under study are located in the Mazovian Lowland $\left(20^{\circ} 35^{\prime}\right.$ $-20^{\circ} 48^{\prime} \mathrm{E}, 52^{\circ} 29^{\prime}-52^{\circ} 32^{\prime} \mathrm{N}$ ), where climatic conditions are typical of extensive flats. The annual sum of precipitation is about $500 \mathrm{~mm}$. Mean annual air temperature in Warsaw (at a distance of about $25 \mathrm{~km}$ from Modlin) is $+7.8^{\circ} \mathrm{C}$ in October, $-2.9^{\circ} \mathrm{C}$ in January, $+7.6^{\circ} \mathrm{C}$ in April. Winter covers a period of $100-110$ days, the number of days with frost is $40-50$, and snow cover lasts for $50-60$ days, on the average (Kondracki, 1969; Dylikowa, 1973).

\subsection{Abiotic Conditions in the Undergrounds}

The forts under study are small, and the lengths of their corridors are $150 \mathrm{~m}$ at Czarnowo, $160 \mathrm{~m}$ at Goławice II, $200 \mathrm{~m}$ at Janowo, $280 \mathrm{~m}$ at Błogosławie, $380 \mathrm{~m}$ at Goławice I, and $400 \mathrm{~m}$ at Strubiny. The forts differ in the shape and distribution of corridors, number and location of entrance holes, etc. "Large" corridors have been distinguished which are 3-3.5 m wide and 2-3 m high, "small" corridors, $1.5-2 \mathrm{~m}$ wide and $2-2.5 \mathrm{~m}$ high, and also chambers of different sizes (up to $10 \mathrm{~m}$ long).

As the number of entrance holes is high, abiotic conditions in the forts largely depends on outside conditions. In some corridors, permanent air circulation precludes stable thermal conditions. In mid-winter, the temperature of even warmest parts of some forts is below freezing point (Czarnowo, Golawice II), and the critical period is January and February. Air humidity in corridor parts most distant from the entrances varies between 80 and $100 \%$. The corridors of forts Janowo, Strubiny and Błogosławie have two storeys, and the lower storey has more stable climate in winter. Walls of some corridors, especially in forts Janowo and Goławice I, have many crevices, and these are preferred hibernation sites for bats. Permanently submerged sections of forts Błogosławie and Goławice I, and also temporarily flooded Strubiny enhance a high relative air humidity $(>90 \%)$. Forts Goławice I, Czarnowo, Błogosławie and Janowo have narrow and several-metre long ventilation shafts blocked from above. The temperature at the highest points of these shafts differs from the temperature in corridors by up to $2^{\circ} \mathrm{C}$. 


\section{METHODS}

The study was conducted during three successive hibernation periods of bats: 18 November, 1979-21 April, 1980, 2 October, 1980-7 April, 1981, and 22 September, 1981-30 April, 1982. In each fort, single censuses were made in the first and in the second half of each month of hibernation. On each census all the bats encountered were captured, identified to species, sexed, and marked with metallic rings on their forearms. The site of capture was described in terms of the way of hanging, height above the corridor floor, and utilization of crevices. Bats were weigthed to the nearest $0.5 \mathrm{~g}$. From December to February, temperature was measured (mercury thermometer) and relative air humidity (hair hygrometer) in places of capture.

To estimate the significance of differences between frequencies, test $\chi^{2}$ was used at $\alpha=0.05$.

To determine the stability of bat populations in the forts, the index of stability was calculated:

$$
I S=\frac{\sum_{j=1}^{n-1} \frac{A_{j}}{j}}{\sum_{i=2}^{n} N_{t}} \cdot \frac{\bar{N}}{N_{\max }}
$$

where $n$ is the number of censuses, $N_{t}$ the number of individuals in the population during census $i, \bar{N}$ mean number of bats, $N_{\max }$ their maximum number, and $A_{j}$ the sum of the $j$-order recaptures for all censuses $(j=1$ : individuals captured on one immediately preceding census, $j=2$ : individuals captured on the census made two censuses earlier, etc.). This index varies from 0 (no stability at all) to 1 (complete stability).

After Gaisler \& Bauerová (1977), the hibernation period of bats in the forts has been divided into autumn (16 August - 31 October), winter (1 November - 15 March), and early spring (16 March - 30 April). When another division is used, this is noted in the text.

\section{RESULTS}

\subsection{Species Composition, Numbers, and Dominance Structure}

In the forts, 1072 bats were marked (Table 1), representing 9 species: Myotis myotis (Borkhausen, 1797), M. nattereri (Kuhl, 1818), M. brandti 
(Eversmann, 1845), M. daubentoni (Kuhl, 1819), M. dasycneme (Boie, 1825), Eptesicus serotinus (Schreber, 1774), Plecotus auritus (L., 1758), P. austriacus (Fischer, 1829), and Barbastella barbastellus (Schreber, 1774). The number of bats differed from one fort to another. The highest number of bats was observed in two largest forts (Golawice I, Strubiny). Although the other forts were of similar sizes, Janowo and Błogosławie were more preferred, whereas Czarnowo and Golawice II were sparsely occupied (Table 1 ).

Table 1

Numbers and dominance structure (in per cent) of the bats observed in the forts. $\mathrm{Bb}-\mathrm{B}$. barbastellus, $\mathrm{Md}-M$. daubentoni, $\mathrm{Mn}-M$. nattereri, $\mathrm{Mm}-M$. myotis, $\mathrm{Pa}-\mathrm{P}$. auritus, Es - E. serotinus, $\mathrm{Pas}-\mathrm{P}$. austriacus, Mds - M. dasycneme, $\mathrm{Mb}-\mathrm{M}$. brandti.

\begin{tabular}{|c|c|c|c|c|c|c|c|c|c|c|}
\hline Locality & $\mathrm{N}$ & $\mathrm{Bb}$ & Md & $\mathrm{Mn}$ & $\mathrm{Mm}$ & $\mathrm{Pa}$ & Es & Pas & Mds & $\mathrm{Mb}$ \\
\hline Strubiny & 305 & 27.1 & 61.8 & 4.9 & 0.3 & 5.2 & - & - & 0.3 & 0.3 \\
\hline Janowo & 17 & 24. & 52 & 14.2 & 4.0 & 3.4 & 0.6 & 1.1 & - & - \\
\hline Błogosławie & 149 & 54.4 & 33.6 & 0.7 & 0.7 & 5.0 & 5.4 & 0.7 & - & - \\
\hline Golawice I & 361 & 72.0 & 10.8 & 4.7 & 8.6 & 2.2 & 0.8 & 0.3 & 0.6 & - \\
\hline Goławice II & 31 & 77.4 & 6.4 & 3.2 & - & 6.4 & 6.4 & - & - & - \\
\hline Czarnowo & 47 & 53.2 & 10.6 & 2.1 & 15.0 & 10.6 & 2.1 & 6.4 & - & 一 \\
\hline Total & 1072 & 48.2 & 35.3 & 5.7 & 4.3 & 4.2 & 1.4 & 0.7 & 0.3 & 0.1 \\
\hline
\end{tabular}

The numerically dominant species was $B$. barbastellus $(48.2 \%)$, which mostly occurred in winter. A high proportion of $M$. daubentoni (35.3\%) was due to their high numbers in autumn. In forts Strubiny and Janowo, unlike in the other forts, $M$. daubentoni was more abundant than $B$. barbastellus. In all the forts, $P$. auritus was more abundant than $P$. austriacus. The least numerous bats, $M$. brandti and $M$. dasycneme, occured only in the largest forts.

\subsection{Site Preference}

The highest preference for relatively warm and humid sites was found in bats of the genus Myotis, most frequently using ventilation shafts and crevices of different types (Table 2). In ventilation shafts, they occupied the highest places, in contrast to B. barbastellus, which were found along the whole hight of the shafts, usually rather low. Almost all individuals of $M$. nattereri and $E$. serotinus occupied crevices, sometimes very deep and narrow. Bats of the genus Plecotus did not use ventilation shafts at all, and often they were exposed when hibernating (especially $P$. austriacus). The latter species occupied places less distant from entrance holes (to $25 \mathrm{~m}$ ) than $P$. auritus, which hibernated even 
In the end sections of the corridors. B. barbastellus and $P$. austriacus were recorded in sites with temperatures below freezing, the former even six times. Typically, the corridors with high air circulation and without crevices were not occupied by bats, except for single $B$. barbastellus. Some shelters, for example, specified crevices, were regularly occupied by bats, and it has been found that some $B$. barbastellus and $M$. daubentoni returned to them in different years.

\section{Table 2}

Site preference of bats in the period December - February. VS - ventilation shafts, CR - crevices, EX - exposed, + - rare (1-25\% of observations), ++average frequency $(26-50 \%),+++-$ frequent $(51-100 \%), \mathrm{n}-$ number of observations or measurements.

\begin{tabular}{|c|c|c|c|c|c|c|}
\hline \multirow[t]{2}{*}{ Species (n) } & \multicolumn{3}{|c|}{$\begin{array}{l}\text { Site of } \\
\text { capture }\end{array}$} & \multirow{2}{*}{$\begin{array}{l}\text { Height } \\
\text { above } \\
\text { corridor } \\
\text { bottom }(\mathrm{m})\end{array}$} & \multirow{2}{*}{$\begin{array}{c}\text { Air tempera- } \\
\text { ture at } \\
\text { capture } \\
\text { sites }\left({ }^{\circ} \mathrm{C}\right)\end{array}$} & \multirow{2}{*}{$\begin{array}{l}\text { Relative } \\
\text { air humidity } \\
\text { at capture } \\
\text { sites }(\%)\end{array}$} \\
\hline & $\overline{\mathrm{VS}}$ & $\mathrm{CR}$ & $\mathrm{EX}$ & & & \\
\hline $\begin{array}{l}\text { M. myotis (14) } \\
\text { M. nattereri }(25) \\
\text { M. daubentoni }(60) \\
E . \text { serotinus (12) } \\
\text { B. barbastellus (84) } \\
\text { P. auritus (22) } \\
P . \text { austriacus (8) }\end{array}$ & $\begin{array}{l}++ \\
+ \\
+ \\
+ \\
+\end{array}$ & $\begin{array}{l}+ \\
+++ \\
+++ \\
++ \\
++ \\
++ \\
+\end{array}$ & $\begin{array}{c}+ \\
+ \\
++ \\
++ \\
+++\end{array}$ & $\begin{array}{l}2.2-7.0 \\
1.5-6.0 \\
0.4-5.5 \\
2.5-5.0 \\
1.5-5.0 \\
1.7-2.5 \\
1.5-2.4\end{array}$ & $\begin{array}{l}+3.5-+6.0 \\
+1.5-+7.0 \\
+0.5-+7.0 \\
+0.5-+6.5 \\
-2.5-+6.5 \\
+1.0-+5.5 \\
-0.5-+4.5\end{array}$ & $\begin{array}{l}86-100 \\
85-100 \\
80-98 \\
78-92 \\
72-98 \\
75-95 \\
69-90\end{array}$ \\
\hline
\end{tabular}

\subsection{Stability of Hibernating Populations}

Changes in numbers of five species were analysed in successive hibernation periods (Fig. 1). In autumn, M. daubentoni and M. myotis, the "autumn" species, appeared earliest, reaching peak numbers in the first half of October. Then their numbers decreased. Since December only several to a dozen or so individuals of both these species were noted, and no clear increase in their numbers was observed in early spring. Much later such species appeared in the undergrounds as $P$. auritus (since mid-October), B. barbastellus, and M. nattereri (early in November) - the "winter" species. Earlier only single individuals of these species were noted. The number of $B$. barbastellus slowly declined during hibernation, and rapidly declined in March or early April. In little abundant $M$. nattereri and $P$. auritus no such tendencies were noted.

It was more difficult to determine the time when bats ultimately left the undergrounds since their numbers were very low in early spring. The species arriving to forts later, that is, B. barbastellus, $M$. nattereri and $P$. auritus, left the forts at the end of March, whereas $M$. daubentoni and especially $M$. myotis, were frequently noted even in April (Fig. 1). 
Changes in numbers and a permanent exchange of individuals observed in most species accounted for a high instability of bat populations during the hibernation period in the undergrounds. This is indicated by the values of the index of stability (IS), which did not exceed 0.2 (Table 3). Because of these low values it is difficult to make interspecific comparisons, although it may be suggested that $B$. barbastellus was more stable than $M$. daubentoni the latter species frequently showing
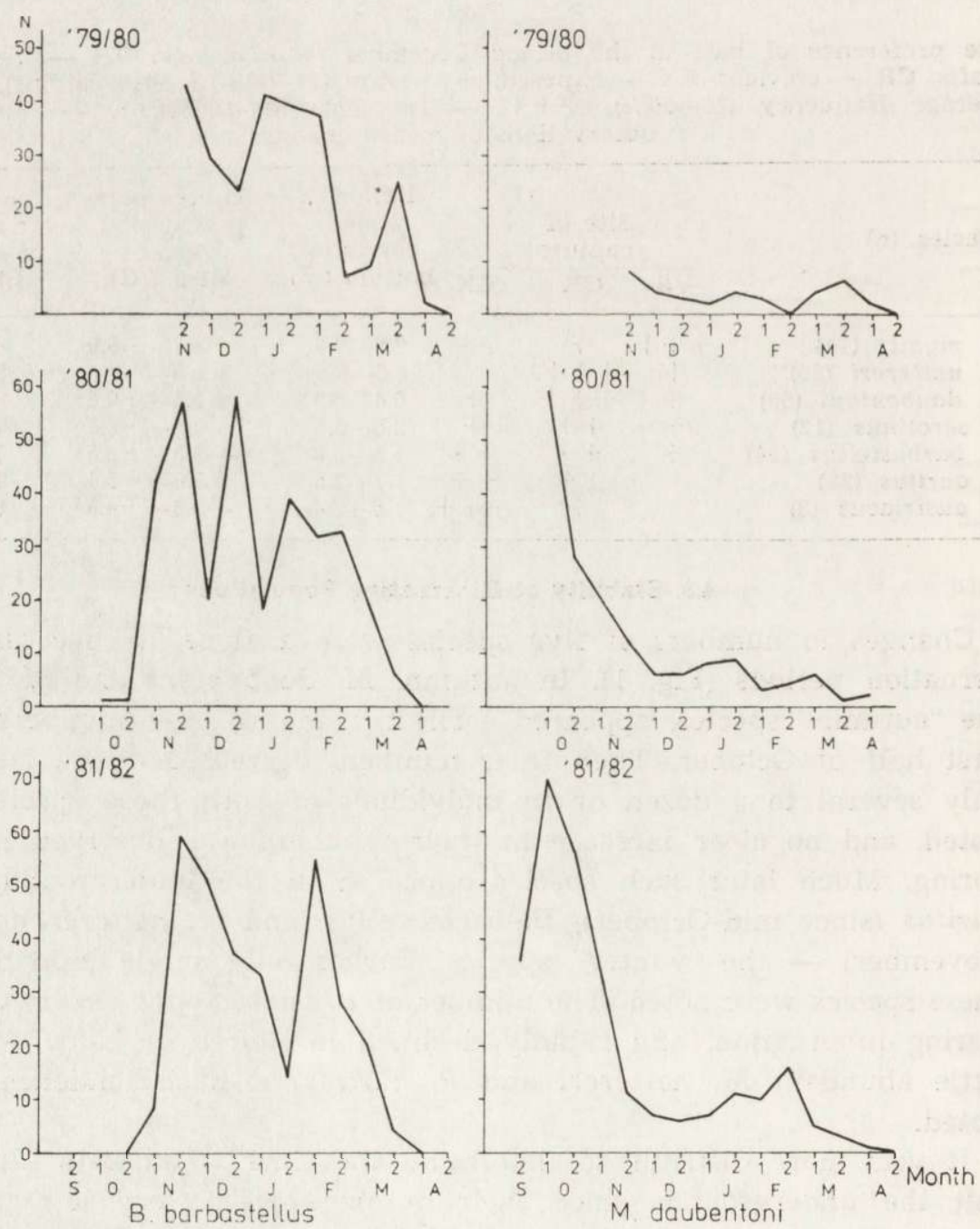

Fig. 1. Changes in numbers of bats $(N)$ in succesive hibernation periods in all the forts. 1 - the first half of each month (1st-15th), 2 - the second half of each month $(>16 \mathrm{th})$. Continued on the next page. 

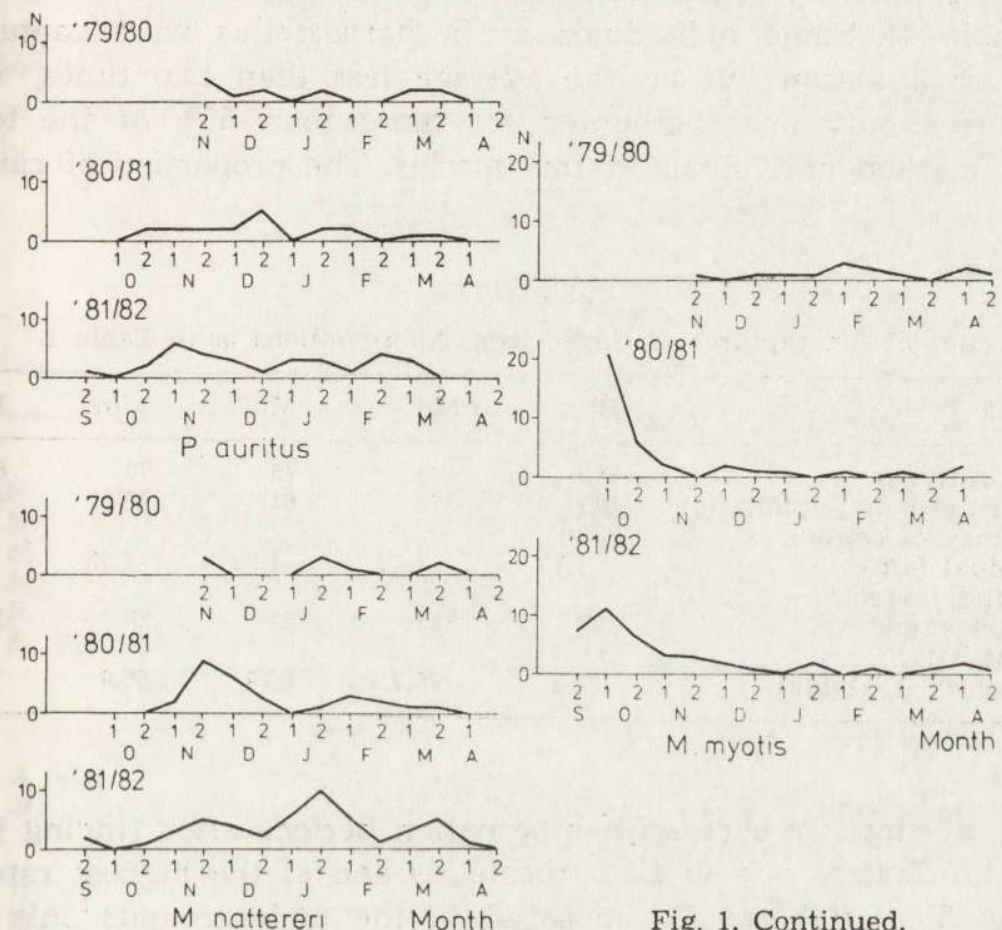

Fig. 1. Continued,

Table 3

Values of the index of stability (IS) for the $B$. barbastellus and $M$. daubentoni populations.

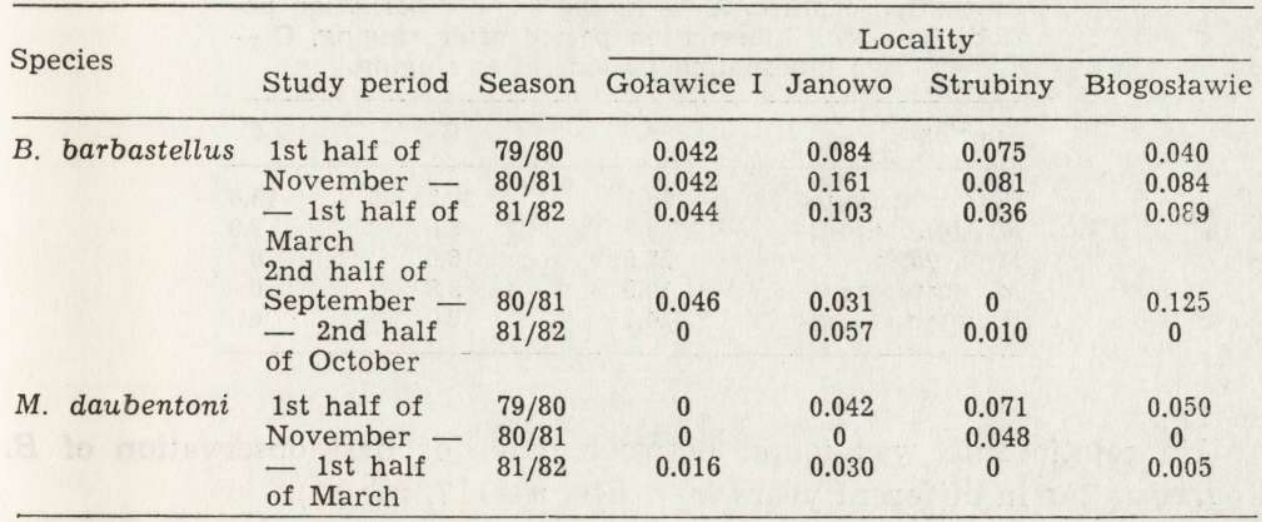

a total lack of stability $(I S=0)$. There is no reason to suggest that there were differences in the stability of the $M$. daubentoni population between autumn and winter, or from one hibernation period to another. 
The most frequently recaptured bats were $M$. myotis and $B$. barbastellus (Table 4). Some individuals of B. barbastellus were captured 7 times over a season but on the average less than two times, and those captured only once accounted for more than $60 \%$ of the total number of marked individuals of this species. The proportion of ringed

Table 4

Frequency of the captures of ringed bats. Abbreviations as in Table 1.

\begin{tabular}{llcccc}
\hline Type of data & $\mathrm{Bb}$ & $\mathrm{Md}$ & $\mathrm{Mn}$ & $\mathrm{Mm}$ & $\mathrm{Pa}$ \\
\hline $\begin{array}{l}\text { Number of captures (a) } \\
\text { Number of ringed individuals (b) }\end{array}$ & 817 & 439 & 75 & 70 & 61 \\
$\begin{array}{l}\text { Mean frequency of capture } \\
\text { per individual (a/b) }\end{array}$ & 1.70 & 1.17 & 1.23 & 1.52 & 1.35 \\
$\begin{array}{l}\text { Number of individuals } \\
\text { captured once (c) }\end{array}$ & 327 & 335 & 53 & 28 & 33 \\
$\begin{array}{l}\text { Proportion of bats } \\
\text { captured once (c/b×100) }\end{array}$ & 63.2 & 89.7 & 86.9 & 60.9 & 75.0 \\
\hline
\end{tabular}

individuals declined in successive hibernation periods after ringing (Table 5), at the lowest rate in $B$. barbastellus and at the highest rate in $P$. auritus. The latter species appeared in the undergrounds only for single hibernation periods.

Table 5

Percentage of recaptured individuals in relation to time after capture. A - in the same hibernation period, B - one hibernation period after ringing, C two hibernation periods after ringing.

\begin{tabular}{lrcc}
\hline Species & A & B & C \\
\hline B. barbastellus & 28.1 & 20.2 & 18.0 \\
M. daubentoni & 8.5 & 3.6 & 2.9 \\
M. myotis & 25.8 & 16.5 & 0 \\
M. nattereri & 10.9 & 3.8 & 0 \\
$P$. auritus & 24.7 & 0 & 0 \\
\hline
\end{tabular}

No relationship was found between dates of first observation of $B$. barbastellus in different years $(r=0.049, n=117, p>0.1)$.

On seven occasions bats moved from one fort to another. These were B. barbastellus ( 6 cases) and $M$. myotis (1 case). Only two times this happened within the same hibernation period, and the distance did not exceed $1.5 \mathrm{~km}$. The other distances were up to $4-6 \mathrm{~km}$. 


\subsection{Sex Ratio}

In seven out of nine species recorded the number of males was higher than that of females, although the difference was statistically significant only for B. barbastellus and E. serotinus (Table 6). Sex ratio varied over

Table 6

Sex ratio of first-captured and recaptured bats.

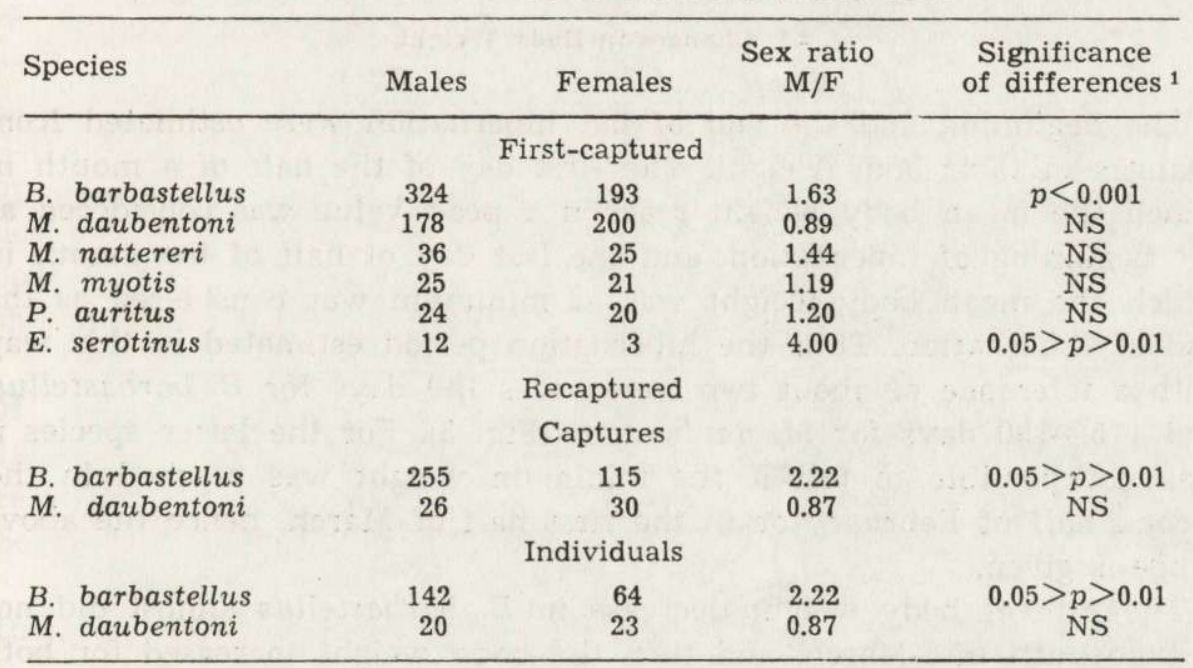

1 For first-captured bats in relation to $1: 1$ ratio, for recaptured bats in relation to the respective ratio of first-captured bats.

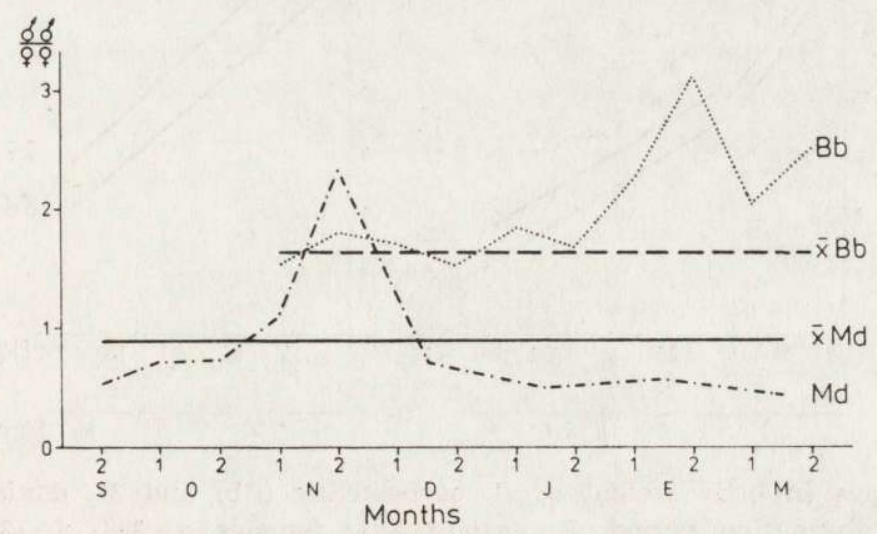

Fig. 2. Changes in sex ratio (mean values) in B. barbastellus (Bd) and $M$. daubentoni (Md) in hibernation periods. Symbols as in Fig. 1. 
the hibernation period as shown for $B$. barbastellus and $M$. daubentoni. The proportion of males clearly increased in both these species, for $M$. daubentoni in November and early in December, and for B. barbastellus from early February until the end of March (Fig. 2).

Among recaptured $B$. barbastellus, the predominance of males was significantly higher than among first-captured individuals. This was not the case for $M$. daubentoni (Table 6).

\subsection{Changes in Body Weight}

The beginning and the end of bat hibernation were estimated from changes in their body weight. The first day of the half of a month in which the mean body weight reached a peak value was considered as the beginning of hibernation, and the last day of half of the month in which the mean body weight was at minimum was considered as the end of hibernation. Thus the hibernation period estimated in this way with a tolerance of about two weeks was 140 days for B. barbastellus, and 175-190 days for $M$. daubentoni (Fig. 3). For the latter species it was not possible to tell if the minimum weight was reached in the second half of February or in the first half of March, hence the above range is given.

The rate of body weight decrease in B. barbastellus almost did not change until mid-March, and then the body weight increased for both

Md

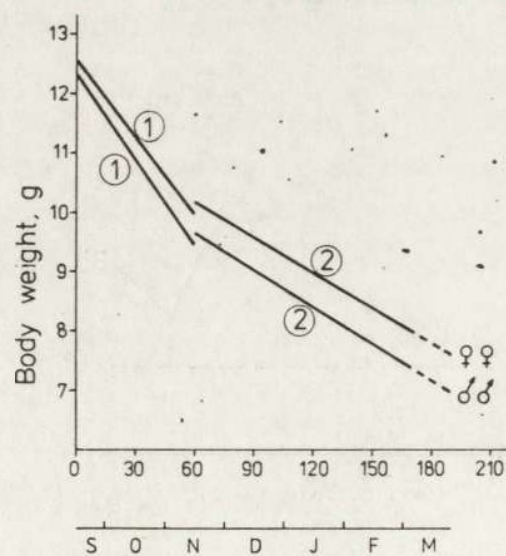

$\mathrm{Bb}$

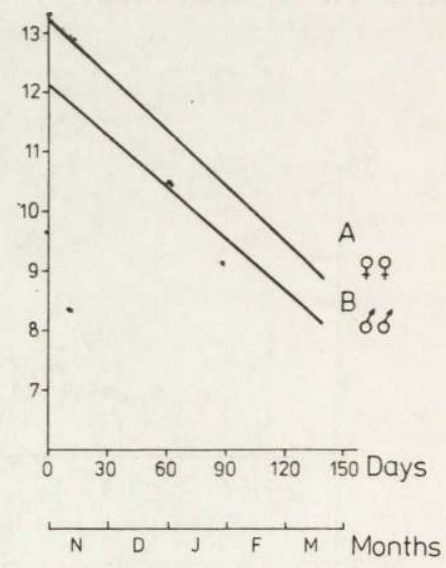

Fig. 3. Changes in body weight of $B$. barbastellus $(\mathrm{Bb})$ and $M$. daubentoni $(\mathrm{Md})$ during the hibernation period. B. barbastellus: females $n=298, y=13.239-0.031 x$; males $n=550, y=12.126-0.029 x$. $M$. daubentoni; females $n_{1}=149, y_{1}=12.598-0.048 x$, $n_{2}=86, y_{2}=10.164-0.018 x$; males $n_{1}=129, y_{1}=12.186-0.045 x, n_{2}=69, y_{2}=9.679-0.018 \mathbf{x}$. The mean body weight of females (A) and males (B) B. barbastellus in the second half of March is shown $\left(n_{A}=10, S D_{A}=0.70, n_{B}=25, S D_{B}=0.54\right)$. 
sexes. In M. daubentoni, daily decreases in body weight in the first part of hibernation (until mid-November) were more than twice as high as in the remaining period (Fig. 3).

\section{DISCUSSION}

In Central Europe the undergrounds with many entrance holes and, consequently, with good air circulation, are readily and abundantly used for hibernation by B. barbastellus (Rybář, 1975; Sklenář, 1981; Bagrowska-Urbańczyk \& Urbańczyk, 1983). In the forts under study, this species found good conditions for hibernation. It also predominated by number, selecting sites with relatively low air temperatures, this being known from the literature (Harmata, 1969; Gaisler, 1970). Temporarily, it can occupy places with temperatures below freezing, which shows that this species is resistant to freezing.

The species frequently noted and sometimes dominant also include M. daubentoni (Haensel, 1973; Bagrowska-Urbańczyk \& Urbańczyk, 1983). It was on the second position in the forts, and this may be related to an increase in the abundance of this species in European hibernation sites in recent years (Bárta et al., 1983; Daan, 1983).

Differences in numbers of some species between forts result from their specific microhabitat requirements in the undergrounds. $M$. nattereri is most abundant in the forts with many crevices available, which is confirmed in the literature (Haitlinger, 1976; Pelikan et al., 1979). The distribution and numbers of $M$. myotis are rather closely related to the presence of blocked ventilation shafts. This species clearly prefers them here, like in the forts of Poznan (Bogdanowicz, 1983). Bats of the genus Myotis are scarce in the region of Modlin in winter, this being related to the range of their thermal preferences (typically +3 to $+8^{\circ} \mathrm{C}$ ) (Harmata, 1969; Gaisler, 1970; Gilson, 1978), which cannot be met in the study forts.

The differential occurrence of most sedentary species ( $P$. auritus, $P$. austriacus, E. serotinus) in the forts can be related to the distribution of their summer shelters. It has been found that $P$. austriacus occupies in the forts sites closer to the entrance holes than $P$. auritus does. This can be explained by a higher preference of the former to small undergrounds (see Horáček, 1975; Haitlinger, 1976). In winter, such sites are more exposed to freezing, thus colder than those preferred by $P$. auritus, typically located deep in the forts.

The stability of bat populations hibernating in the udergrounds is generally low (e.g. Verschuren, 1949; Krzanowski, 1959). A similar situation was observed in this study, and a little higher stability of 
B. barbastellus as compared with $M$. daubentoni shows that the former is more dependent on the wintering sites of this type.

The occurrence of the species called here "autumn" species in some undergrounds has not been explained so far, and also the hibernation places of the individuals appearing during the autumn peak numbers are not known. The "autumn" species from the study forts (M. myotis and $M$. daubentoni) showed similar changes in numbers in Puławy (Krzanowski, 1959) and in the region of Leningrad (Strelkov, 1971). According to Twente (1955), staying in the undergrounds in late summer, which are rather cool shelters relative to other shelter types at this time of the year, enables bats a rapid accumulation of fat before hibernation. The fact that they move from one place to another over the hibernation period suggests that they can use also other types of shelters as wintering sites, and their changes in numbers observed in the undergrounds reflect their movements from one shelter to another. Temperature falls account for a rise of bat numbers in the undergrounds (Hanák \& Gaisler, 1959; Lesiński, 1983), providing evidence that they also occupy thermally less isolated shelters such as lofts and tree holes.

The higher number of males than females recorded for B. barbastellus and E. serotinus in Modlin, has frequently been noted in the undergrounds (e.g. Davis, 1959; Gauckler \& Kraus, 1963; Feldmann, 1973). Also changes in the sex ratio during hibernation are known from the literature (Krzanowski, 1959; Gaisler, 1963; Daan, 1973), but they are not consistent with the results of this study.

Taking into account that numbers of bats in the undergrounds vary and that there is a permanent exchange of individuals, it is difficult to estimate the duration. of the hibernation period. Typically, in the literature the time of the occurrence of bats in the undergrounds is given. The method described here, based on the analysis of changes in body weight, seems to be more appropriate. Its accuracy can be increased by distinguishing shorter time periods. $B$. barbastellus occur in the forts even after reaching the minimum body weight, thus after the ending of hibernation.

$M$. daubentoni belongs to the species with longest hibernation period (Strelkov, 1971; Daan, 1973), in contrast to B. barbastellus (Rybár., 1975), and this is confirmed in the present study. Bats beginning hibernation in early autumn, e.g. M. daubentoni, loose weight at a much higher rate in the early period of hibernation than in winter (similar observations are reported by Strelkov, 1971; Daan, 1973; Funakoshi \& Uchida, 1978). This may be explained by the fact that air temperatures in the undergrounds at that time of the year are too high in relation to the optimum, and they accelerate metabolic rate. 
Acknowledgements: I wish to thank all my colleagues who co-operated in the field work, and assisted in analysing the collected material. I am grateful to Professors Kazimierz A. Dobrowolski, Adam Krzanowski and Jan Pinowski, and to Doctor Andrzej L. Ruprecht for comments to the preliminary version of this text.

\section{REFERENCES}

1. Bagrowska-Urbańczyk E. \& Urbańczyk Z., 1983: Structure and dynamics of a winter colony of bats. Acta theriol., 28: 183-196.

2. Bartá Z., Cervený J., Gaisler J., Hanák P., Hanák V., Horáček I., Hůrka L., Miles P., Nevrlý M., Rumler Z., Sklenář J. \& Žalman J., 1981: Výsledky zimniho sčitáni netopýrů v Ceskoslovensku: 1969-1979. Sb. Okresniho muzea v Mostě, Rada přir., 3: 71-116.

3. Bogdanowicz W., 1983: Community structure and interspecific interactions in bats hibernating in Poznań. Acta theriol., 28: 357-370.

4. Daan S., 1973: Activity during natural hibernation in three species of vespertilionid bats. Neth. J. Zool., 23: 1-71.

5. Daan S., 1983: Long term changes in bat populations in the Netherlands: a summary. Lutra, 22: 95-105.

6. Davis W. H., 1959: Disproportionate sex ratios in hibernating bats. J. Mammal., 40: 16 - 19 .

7. Dylikowa A., 1973: Geografia Polski. Krainy geograficzne. PWN: 1-816. Warszawa.

8. Feldmann R., 1973: Ergebnisse zwanzigjährigen Fledermausmarkierungen in westfälischen Winterquartieren. Abh. Landesmuseum f. Naturkd., 35: 3-26.

9. Funakoshi K. \& Uchida T. A., 1978: Studies on the physiological and ecological adaptation of temperate insectivorous bats. II: Hibernation and winter activity in some cave dwelling bats. Jap. J. Ecol., 28: 237-261.

10. Gaisler J., 1963: The ecology of lesser horseshoe bat (Rhinolophus hipposideros hipposideros Bechstein, 1800) in Czechoslovakia. Part I. Věst. Cs. spol. zool., 27: $211-233$.

11. Gaisler J., 1970: Remarks on the thermopreferendum of Palearctic bats in their natural habits. Bijdr. Dierk., 40: 33-35.

12. Gaisler J. \& Bauerová Z., 1977: Společenstvo netopýrů (Chiroptera) na Kvĕtnicy během třiceti let. Lynx, 19: 17-28.

13. Gauckler A. \& Kraus M., 1963: Uber ein Massenquartier winterschlafender Mausohren (Myotis myotis) in einer Höhle der Frankenalb. Bonn. zool. beitr., 14: $187-205$.

14. Gilson R., 1978: Notes sur le thermopreferendum et l'emplacement préférentiel du vespertilion des marais (Myotis dasycneme), pendant l'hibernation. Bull. du Centre de Baguement et the Recherche Chiropt. de Belg., 5: 74-95.

15. Haensel J., 1973: Über die Saisonwanderung der Wasserfledermäuse, Myotis daubentoni Leisl. ausgehend vom Massenwinterquartier Rüdersdorf (Mammalia, Chiroptera). Zool. Abh., 32: 249-255.

16. Haitlinger R., 1976: Nietoperze Dolnego Sląska. Przegl. zool., 20: 124-134.

17. Hanák V. \& Gaisler J., 1959: Ekologické poznámky k zimováni netopýrů. Cas. Nár. Mus., 128: 17-26.

18. Harmata W., 1969: The thermopreferendum of some species of bats (Chiroptera). Acta theriol., 16: 49-62.

19. Horáček I., 1975: Notes on the ecology of bats of the genus Plecotus Geoffroy, 1818 (Mammalia: Chiroptera). Věst. Cs. spol. zool., 39: 195-210. 
20. Kondracki J., 1965: Geografia fizyczna Polski. PWN: 1-575. Warszawa.

21. Krzanowski A., 1959: Some major aspects of population turnover in wintering bats in the cave at Pulawy (Poland). Acta theriol., 3: 27-43.

22. Lesiński G., 1980: Nowe stanowiska nocka dużego Myotis myotis (Borkhausen, 1797) na Mazowszu. Przegl. zool., 24: 215-220.

23. Lesiński G., 1983: Nietoperze jaskiń Wyżyny Wieluńskiej. Przegl. zool. 27: $465-478$.

24. Pelikan J., Gaisler J. \& Rödl P., 1979: Naši savci. Academia: 1-163. Praha.

25. Rybař P., 1975: Hibernation of the barbastelle, Barbastella barbastellus (Schreber, 1774) in a man-made hibernation quarter. Zool. Listy, 24: 113-124.

26. Sklenař J., 1981: Deset let výskumu zimoviště netopýrů (Chiroptera) v Orlických horách. Acta Musei Reginaehradecensis A, 16: 273-288.

27. Strelkov P. P., 1971: Ekologičeskie nabljudenija za zimnej spjackoj letučich myšej (Chiroptera, Vespertilionidae) Leningradskoj oblasti. [In: "Morfologija i ekologija pozvonočych", Ed. B. E. Bychovskij], Trudy Zool. Inst. AN SSSR, 48: $251-302$.

28. Twente J. W., 1955: Some aspects of habitat selection and other behaviour of cavern dwelling bats. Ecology, 36: 706-732.

29. Verschuren J., 1949: L'activite et les deplacements hivernaux des chiropteres en Belgique. Inst. royal des Sc. natur. de Belg., Bull., 25: 1-7.

Accepted, April 10, 1986.

Grzegorz LESIŃSKI

\section{EKOLOGIA NIETOPERZY HIBERNUJACYCH W PODZIEMIACH W SRODKOWEJ POLSCE}

Streszczenie

Badania prowadzono $\mathrm{w}$ podziemiach fortów twierdzy modlińskiej w ciągu 3 ckresów hibernacji nietoperzy $(1979 / 80,1980 / 81,1981 / 82)$. Podziemia kontrolowano dwukrotnie w ciągu miesiąca, odławiając 1 znakując wszystkie dostępne nietoperze. Zanotowano obecność 1072 osobników należących do 9 gatunków, spośród których dominującymi liczebnie są: B. barbastellus $(48.2 \%)$ i $M$. daubentoni $(35.3 \%)$. Przedstawiono charakterystyki miejsc wybieranych przez poszczególne gatunki w okresie zimowym: w najchłodniejszych występują $B$. barbastellus i $P$. austriacus, a w najcieplejszych nietoperze $\mathrm{z}$ rodzaju Myotis (Tabela 2).

Wyróżniono gatunki ,jesienne” ( $M$. myotis i $M$. daubentoni), których szczyt liczebności przypada na początek października oraz gatunki „zimowe”, które w większej liczbie przylatują do podziemi w listopadzie (B. barbastellus, P. auritus, M. nattereri i prawdopodobnie $P$. austriacus i E. serotinus). W ciągu całego okresu hibernacji następuje stała wymiana osobników w podziemiach (wartości wskaźnika stabilności $I S<0.2$ - Tabela 3), która nie jest efektem przelotów pomiędzy fortami. Największą stabilność wykazują populacje $B$. barbastellus (Tabele 3,4 i 5 ). Udział osobników odławianych częściej niż raz najwyższy jest u $M$. myotis $-39.1 \%$ 
i B. barbastellus - 36.8\%. P. auritus już w następnym po oznakowaniu okresie hibernacji nie powraca do fortów.

Populacje B. barbastellus i E. serotinus, zasiedlające badane podziemia, charakteryzuje istotna statystycznie przewaga samców, przy czym stosunek płci ulega wahaniom w okresie hibernacji (Tabela 6, Ryc. 2). Wśód znakowanych B. barbastellus odławianych powtórnie istotnie częstsze są samce (Tabela 6).

Srednie dobowe spadki ciężaru ciała $M$. daubentoni w pierwszej części hibernacji $(0.045-0.048 \mathrm{~g})$ są ponad dwukrotnie większe niż w zimie $(0.018 \mathrm{~g})$. U $B$. barbastellus tempo spadku ciężaru ciała jest w całym okresie przebywania w fortach w przybliżeniu równe $(0.029-0.031 \mathrm{~g}$ na dobę) (Ryc. 3). Czas trwania hibernacji, określony na podstawie analizy zmian ciężaru ciała, jest dłuższy u M. daubentoni: 175-190 dni, niż u B. barbastellus: 140 dni. 